\title{
Editorial
}

\section{Geo-Informatics in Resource Management}

\author{
Francisco Javier Mesas-Carrascosa $\mathbb{D}$ \\ Department of Graphic Engineering and Geomatics, University of Cordoba, Campus de Rabanales, \\ 14071 Cordoba, Spain; fjmesas@uco.es
}

Received: 23 October 2020; Accepted: 23 October 2020; Published: 26 October 2020

\begin{abstract}
Natural resource management requires reliable and timely information available at local, regional, national, and global scales. Geo-informatics, by remote sensing, global navigation satellite systems, geographical information systems, and related technologies, provides information for natural resource management, environmental protection, and support related to sustainable development. Geo-informatics has proven to be a powerful technology for studying and monitoring natural resources as well as in generating predictive models, making it an important decision-making tool. The manuscripts included in this Special Issue focus on disciplines that advance the field of resource management in geomatics. The manuscripts showcased here provide different examples of challenges in resource management.
\end{abstract}

Keywords: remote sensing; geographic information system; land use; disaster management

\section{Introduction}

Throughout time, humanity has watched, taken data and studied the sky, oceans and continents in order to be able to explain natural phenomena such as eclipses, earthquakes and tides. In the beginning, it was a challenge to be able to take measurements and observations in a scientific framework, registering data in field notebooks that were later interpreted through maps, profiles or sections. The development and technological evolution have radically changed the tools used, working with sensors on-board satellite platforms and manned or unmanned air vehicles, global satellite navigation systems and web services and platforms among others. Despite all this, there are still difficulties in achieving integrated knowledge of the phenomena that occur in such a complex system as our planet Earth. In addition, more and more data are being recorded, which makes interpretation and analysis more difficult due to its large volume and heterogeneity. All the advances that are taking place in the geosciences are due to innovative approaches based on the interoperability, integration, modeling and analysis of geodatabases. In this context, Geo-informatics provides the ability to handle a wide range of spatial-temporal scales, heterogeneous data and visualize and analyze the data from an analytical point of view.

Geo-informatic research involves using new information methods and technologies, software suites, geo-databases, the internet and developing software. These techniques are successfully used in a broad range of areas of knowledge like urban planning [1,2], conservation and promotion of cultural heritage [3,4], marketing [5], agriculture [6,7], forestry [8,9], air quality monitoring [10,11] and water pollution [12,13] among many others.

\section{The Contribution of This Special Issue}

The articles included in this Special Issue (SI) focus on resource management applications using different tools and sensors that advance fields like seismology, disaster management and natural wetlands dynamics. All these contributions show challenging examples of resource management tackled from different points of view. 
The first group of manuscripts use images from sensors on-board satellite, manned and unmanned aerial platforms. Firstly, Wang et al. [14] used images from satellite platforms for crop management. They validated leaf area index from Moderate Resolution Imaging Spectroradiometer (MODIS) products using a multi-scale validation on corn and rice growth cycles. Results were overestimated during the medium growth stage and underestimated during the other growth stages like flowering or maturity. They suggested that higher spatial resolution images should be explored. From another point of view, Ma et al. [15] used active fire products and night-time light data based on satellite images to show and monitor spatial and temporal patterns of heavy industrial economic development and, therefore, valuable information for policymakers. For images obtained with sensors on-board manned aerial platforms, there are three contributions. Firstly, Przemyslaw et al. [16] assessed the applicability of texture analysis to study the dynamics of the succession of trees and shrubs using aerial imagery acquired in six different years in various phenological periods, resulting in an effective method for determining the extent of wooded and shrubbed areas. Ruiz-Lendínez [17] located and mapped abandoned farmlands, applying textural characterization on high spatial resolution aerial imagery. Finally, Chen et al. [18] estimated fraction vegetation cover on five grassland types using unmanned aerial images, applying the threshold method. Results were highly reliable, although it was necessary to take into account the heterogeneity of the underlying surface using the sample method.

The second group of manuscripts uses geographic information systems to support decision making. Maqbool et al. [19] proposed a model for analysis of disaster management strategies at urban scales while Amaro and Tien [20] used Geographic Information System (GIS) to study seismic parameters to calculate and analyze seismic indicators. In addition, Wang et al. [21] used base cartography, lithology and seismic intensity data and GIS modelling to quantitatively evaluate the ecological and geological environment bearing capacity along a mountain road to characterize those areas suitable and not suitable for construction as well as reserve development areas. On the other hand, Zhou et al. [22] explored spatial patterns of natural wetland dynamics by applying Moran's statistics for decision-making conservation based on GIS. Finally, Navarro et al. [23] applied cellular automata-based land-use modeling to simulate and predict land-use dynamics and landscape.

In addition to contributions focused on land resources, in the case of maritime management, Xiao et al. [24] proposed a maritime oil flow analysis framework using data obtained by web scraping techniques and information from administrations to increase the security and stability of energy transportation.

New geo-information technologies have changed the way resources are managed. The current trend is pushing towards new scenarios where large volumes of heterogeneous data coexist in the decision-making process. In this scenario, these new utilities in geosciences require that scientists continue to develop new tools and analytical approaches that motivate current research priorities. The future relies on fostering collaboration and sharing ideas across subject/discipline boundaries, between researchers and final users, enabling communities to exploit the knowledge inherent in our digital earth.

Funding: This research received no external funding.

Conflicts of Interest: The author declares no conflict of interest.

\section{References}

1. Tripathy, P.; Kumar, A. Monitoring and modelling spatio-temporal urban growth of Delhi using Cellular Automata and geoinformatics. Cities 2019, 90, 52-63. [CrossRef]

2. Makinde, E.O.; Agbor, C.F. Geoinformatic assessment of urban heat island and land use/cover processes: A case study from Akure. Environ. Earth Sci. 2019, 78, 483. [CrossRef]

3. Xiao, W.; Mills, J.; Guidi, G.; Rodríguez-Gonzálvez, P.; Gonizzi Barsanti, S.; González-Aguilera, D. Geoinformatics for the conservation and promotion of cultural heritage in support of the UN sustainable development goals. ISPRS J. Photogramm. Remote Sens. 2018, 142, 389-406. [CrossRef] 
4. Monego, M.; Menin, A.; Fabris, M.; Achilli, V. 3D survey of Sarno Baths (Pompeii) by integrated geomatic methodologies. J. Cult. Herit. 2019, 40, 240-246. [CrossRef]

5. Afnarius, S.; Akbar, F.; Yuliani, F. Developing web-based and mobile-based GIS for places of worship information to support halal tourism: A case study in Bukittinggi, Indonesia. ISPRS Int. J. Geo-Inf. 2020, 9, 52. [CrossRef]

6. Segarra, J.; Buchaillot, M.L.; Araus, J.L.; Kefauver, S.C. remote sensing for precision agriculture: Sentinel-2 improved features and applications. Agronomy 2020, 10, 641. [CrossRef]

7. Weiss, M.; Jacob, F.; Duveiller, G. Remote sensing for agricultural applications: A meta-review. Remote Sens. Environ. 2020, 236, 111402. [CrossRef]

8. Guimarães, N.; Pádua, L.; Marques, P.; Silva, N.; Peres, E.; Sousa, J.J. Forestry Remote sensing from unmanned aerial vehicles: A review focusing on the data, processing and potentialities. Remote Sens. 2020, 12, 1046. [CrossRef]

9. Gibson, R.; Danaher, T.; Hehir, W.; Collins, L. A remote sensing approach to mapping fire severity in south-eastern Australia using sentinel 2 and random forest. Remote Sens. Environ. 2020, 240, 111702. [CrossRef]

10. Mesas-Carrascosa, F.-J.; Pérez Porras, F.; Triviño-Tarradas, P.; García-Ferrer, A.; Meroño-Larriva, J.E. Effect of lockdown measures on atmospheric nitrogen dioxide during SARS-CoV-2 in Spain. Remote Sens. 2020, 12, 2210. [CrossRef]

11. Badach, J.; Voordeckers, D.; Nyka, L.; Van Acker, M. A framework for air quality management zones-useful GIS-based tool for urban planning: Case studies in Antwerp and Gdańsk. Build. Environ. 2020, 174, 106743. [CrossRef]

12. Dias, M.A.; Silva, E.A.; da Azevedo, S.C.; de Casaca, W.; Statella, T.; Negri, R.G. An incongruence-based anomaly detection strategy for analyzing water pollution in images from remote sensing. Remote Sens. 2020, 12, 43. [CrossRef]

13. Cherif, E.K.; Salmoun, F.; Mesas-Carrascosa, F.J. Determination of bathing water quality using thermal images Landsat 8 on the west coast of tangier: Preliminary results. Remote Sens. 2019, 11, 972. [CrossRef]

14. Wang, T.; Qu, Y.; Xia, Z.; Peng, Y.; Liu, Z. Multi-scale validation of MODIS LAI products based on crop growth period. ISPRS Int. J. Geo-Inf. 2019, 8, 547. [CrossRef]

15. Ma, C.; Niu, Z.; Ma, Y.; Chen, F.; Yang, J.; Liu, J. Assessing the distribution of heavy industrial heat sources in India between 2012 and 2018. ISPRS Int. J. Geo-Inf. 2019, 8, 568. [CrossRef]

16. Kupidura, P.; Osińska-Skotak, K.; Lesisz, K.; Podkowa, A. The Efficacy Analysis of determining the wooded and shrubbed area based on archival aerial imagery using texture analysis. ISPRS Int. J. Geo-Inf. 2019, 8, 450. [CrossRef]

17. Ruiz-Lendínez, J.J. Abandoned farmland location in areas affected by rapid urbanization using textural characterization of high resolution aerial imagery. ISPRS Int. J. Geo-Inf. 2020, 9, 191. [CrossRef]

18. Chen, J.; Zhao, X.; Zhang, H.; Qin, Y.; Yi, S. Evaluation of the accuracy of the field quadrat survey of alpine grassland fractional vegetation cover based on the satellite remote sensing pixel scale. ISPRS Int. J. Geo-Inf. 2019, 8, 497. [CrossRef]

19. Maqbool, A.; Afzal, F.; Razia, A. Disaster mitigation in Urban Pakistan using agent based modeling with GIS. ISPRS Int. J. Geo-Inf. 2020, 9, 203. [CrossRef]

20. Amaro-Mellado, J.L.; Tien Bui, D. GIS-Based mapping of seismic parameters for the Pyrenees. ISPRS Int. J. Geo-Inf. 2020, 9, 452. [CrossRef]

21. Wang, Z.; He, X.; Zhang, C.; Xu, J.; Wang, Y. Evaluation of geological and ecological bearing capacity and spatial pattern along du-wen road based on the analytic hierarchy process (AHP) and the technique for order of preference by similarity to an ideal solution (TOPSIS) method. ISPRS Int. J. Geo-Inf. 2020, 9, 237. [CrossRef]

22. Zhou, T.; Niu, A.; Huang, Z.; Ma, J.; Xu, S. Spatial relationship between natural wetlands changes and associated influencing factors in mainland China. ISPRS Int. J. Geo-Inf. 2020, 9, 179. [CrossRef] 
23. Navarro Cerrillo, R.M.; Palacios Rodríguez, G.; Clavero Rumbao, I.; Lara, M.Á.; Bonet, F.J.; Mesas-Carrascosa, F.-J. Modeling major rural land-use changes using the GIS-based cellular automata metronamica model: The case of Andalusia (Southern Spain). ISPRS Int. J. Geo-Inf. 2020, 9, 458. [CrossRef]

24. Xiao, Y.; Chen, Y.; Liu, X.; Yan, Z.; Cheng, L.; Li, M. Oil flow analysis in the maritime silk road region using AIS data. ISPRS Int. J. Geo-Inf. 2020, 9, 265. [CrossRef]

Publisher's Note: MDPI stays neutral with regard to jurisdictional claims in published maps and institutional affiliations.

(C) 2020 by the author. Licensee MDPI, Basel, Switzerland. This article is an open access article distributed under the terms and conditions of the Creative Commons Attribution (CC BY) license (http://creativecommons.org/licenses/by/4.0/). 